\title{
Problems of formation of turistic-recreational complex in Irkutsk Region
}

The key direction of development of economy of Irkutsk region is forming a modern touristic and recreational complex of international importance. Presence of a unique natural object - lake Baikal - is undoubtable competitive advantage of the region.

The region possesses considerable touristic and recreational potential. The rich fauna of Baikal and its coast, presence of rare and vanishing species of plants, abundance of nature sanctuaries (capes, rocks, caves, islands), history and culture, a variety of hydromineral resources make a basis for expansion of intensive recreational activity.

The factors defining prospects of development of such a complex in Irkutsk region are presented in the tab. 1 .

Tab. 1. Potential of recreational complex of Irkutsk region

\begin{tabular}{|l|l|}
\hline Factors & Potential \\
\hline $\begin{array}{l}\text { Natural and climatic } \\
\text { resources of the area }\end{array}$ & $\begin{array}{l}\text { Pribajkalsky national park, Bajkal-Lena and Vitim reserves, 13 special } \\
\text { environmental regim territories of regional importance, 78 nature sanc- } \\
\text { tuaries of which 4 are federal, 30 regional and 44 local. The very lake } \\
\text { Baikal - the deepest lake in the world, a unique natural ecosystem. A sys- } \\
\text { tem of mountain ridges (Hamar-Daban, Primorsky, Baikalsky), where ski } \\
\text { routs and resorts can be built. }\end{array}$ \\
\hline $\begin{array}{l}\text { Cultural and historical } \\
\text { potential }\end{array}$ & $\begin{array}{l}\text { Irkutsk is the oldest city of Eastern Siberia possessing a unique historical } \\
\text { and cultural heritage. In the city with more than 300 years history, there } \\
\text { are about 1200 monuments of Russian history and culture. In the region, } \\
\text { traditions of national art and crafts are saved. Russian culture coexists and } \\
\text { interacts here with Buryat Buddhist and Buryat shamanist traditions. }\end{array}$ \\
\hline Balneal resources & $\begin{array}{l}\text { In the territory of Irkutsk region, Angara-Lena artesian pool of mineral } \\
\text { waters is situated the stocks of which are estimated 2700 cubic km (the } \\
\text { largest in the world). 6 mud lakes of the best genetic types and about 300 } \\
\text { chink mineral sources have been found. }\end{array}$ \\
\hline
\end{tabular}


The territory of Irkutsk region is characterized by rather favorable climate, the access to lake Baikal is a precondition of development of various kinds of rest on water. Possessing a basic infrastructure, the area has the possibility to develop various kinds of tourism (fig. 1).

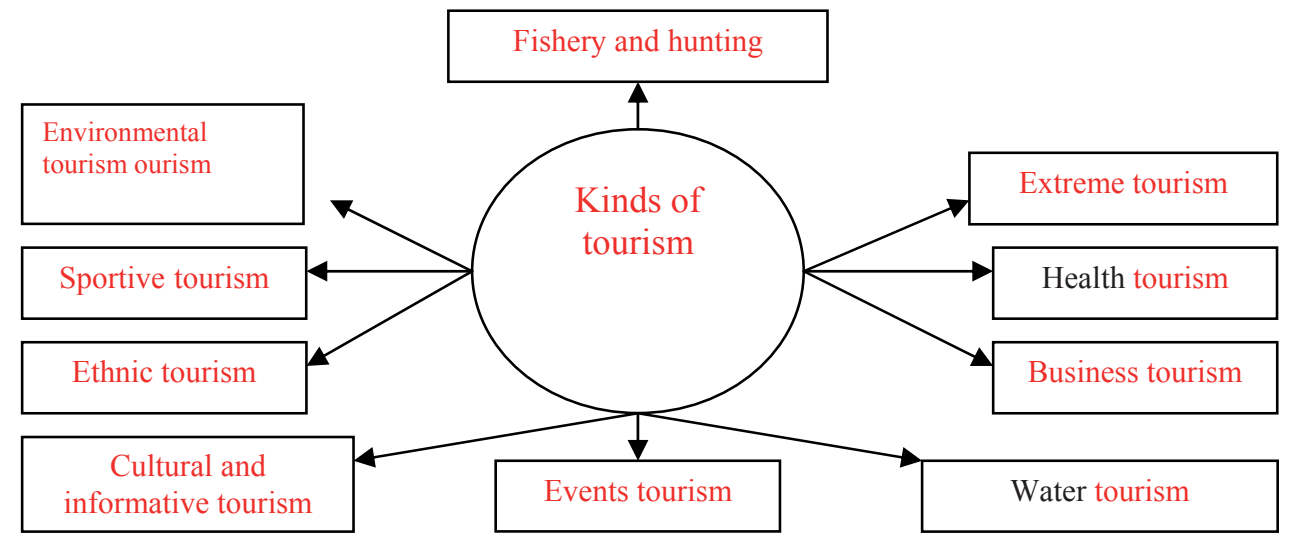

Fig. 1. Kinds of tourism in Irkutsk region

Development of tourist branch can become one of prime projects of development of inter-regional cooperation within the limits of the Siberian federal district. The major element of branch system is creating a zone of touristic-recreational type as a material base of the touristic industry and the main object concentrating the basic essence of the tourist product which will distinguish the Irkutsk region from other Siberian regions.

However the recreational complex of Irkutsk region is characterized by a number of essential lacks which do not allow to use the territory potential in full scale and to make tourism a highly profitable sector of regional economy.

The basic problem consists in the fact that the material base of the sector has been essentially obsolete and does not correspond to the international standards. The current state of tourist complex of Irkutsk region is characterized by:

- an insufficient level of development of means of placing, transport infrastructure, information supply;

- absence of an effective mechanism of stimulation of private investments for development of hospitality industry of;

- the limited set of offered tourist products;

- strongly expressed seasonal prevalence of tourism;

- absence of corresponding material resources and organizational culture for carrying out actions in the sphere of business tourism.

The purpose of creating the zone of turistic-recreational type is formation of a complex of elements of tourist industry as a starting project of an intersectoral cluster and the base of sustainable development of entry and internal tourism of Irkutsk region, on the basis of realization of the mechanism of state-private partnership.

Tourism development in Pribaikalye assumes a set of measures within the limits of the branch policy and, besides, infrastructure development as its today state is one of the factors constraining expansion of tourist streams to Irkutsk region. 
For the tourist complex of Pribaikalye, the airport «Irkutsk» is a key link of business. Annually Irkutsk region is visited by about 250 thousand tourists from the Western regions of Russia and about 100 thousand foreigners, most of which arrive in Irkutsk by planes. Now the airport serves the flights of 23 airlines in 42 cities of various countries of the world and the CIS countries. Charter passenger transportations are carried out to Thailand, Turkey, Mongolia, China, Vietnam, South Korea, Japan, Malaysia, Laos, Maldives, Poland and Bulgaria.

According to some estimations, touristic and recreational sphere development on the bancs of Baikal can give an increase of general passengers flow through Irkutsk airport up to 1,3 million persons a year by 2010 . To serve this increasing volume of passenger traffic, reconstruction of the existing airport is provided.

Serving the growing flow of tourists, in particular on the territory of Pribajkalsky national park, is impossible also without building the modern road infrastructure, capable to open overland access to perspective recreational territories.

Solving the problems of transport infrastructure assumes maximum volume of financial investments from the budgets of all levels. Mechanisms of the state support of the branch can be different:

- acceptance of a special Federal target program of development of tourism on Baikal;

- creation of a special economic turistic-recreational zone according to the legislation of the Russian Federation.

Today, there exists a decision of Federal authorities to create in Irkutsk region a special economic zone of turistic-recreational type «The Gate of Baikal». Its purpose is building of an all-weather resort of world level for attracting various target groups of tourists from Russia, the CIS countries, Europe and Asia, to the coast of lake Baikal and organization of all-the-year-round tourism on Baikal. Besides, emerging such a zone will promote attracting additional investments into the region and creation of new working places.

Development of the zone «The Gate of Baikal» will allow:

1) to generate conditions for the region sustainable development;

2) to create in the region the new tourist sector aimed at a rational and effective utilization of natural-geographical potential of the area;

3) to increase the investment attractiveness of Irkutsk region;

4) to improve the state of economy of Irkutsk region;

5) to use the-recreational potential of the lake Baikal effectively.

Alongside with the state grants, attracting private capital is necessary, especially at this very stage of modernization of tourist sector of the region. In tourist sector, the practice of private-state partnership looks quite effective. The policy of attracting private investors should be based on the mechanisms of decrease of administrative barriers, the system of cheap crediting of small business, tax privileges and state guarantees to businessmen.

Another problem, solving of which will allow to raise essentially region incomes from tourist activity, is alignment of seasonal prevalence of tourist flows in Irkutsk region. The basic tourist season is now only $2-3$ summer months that reduces profitability of the tourist industry and aggravates the problem of employment in the rest time of year.

Tour operators of Irkutsk actively study questions of development of winter tourism on Baikal. So, for example, the company «Sputnik-Baikal» will organise such event actions, as: 
- sports-tourist reality show «Call of the Ancestors». It is a multistage race across Baikal on skis, snowmobiles and the dog teams (all about $120 \mathrm{~km}$ in 3 days). The winner of the race will receive a gold nugget;

- traditional Transbaikal $38 \mathrm{~km}$ ice crossing along 105th meridian in March. Hot meals for participants and short-term rest will be organized in ice camp precisely on the middle of Baikal;

- races on ice floes broken away from the ice armor of Baikal. Racers will pass about $3 \mathrm{~km}$ on nonfreezing source of the river Angara and finish at the mooring of hotel complex «Anastasia»;

- in February 2010 it is planned to arrange the first race of the regional stage of the international tourist project «The tea caravan». From Ulan-Ude to Irkutsk on the ice of lake Baikal on the dog teams and snowmobiles tea will be delivered brought from China on the historical tea way.

The next block of problems of recreational complex development is presented by the questions of creation of the international image of Irkutsk region as a tourist centre of Eastern Siberia. The region positioning should be based on uniqueness, availability, high level of service of the tourist product. As concrete actions it is possible to allocate the following:

- working out the regional image as a whole and tourism corporate style in the region;

- creating and distributing in Russia and abroad the advertising materials about tourist and sanitary possibilities of the area;

- editing maps, guidebooks, brochures, video data;

- promoting new tourist and sanitary resources;

- organizing presentations of new tourism products and advertising rounds with invitation of tour operators and tourist agencies;

- work at the international exhibitions and fairs, accompanied by advertising and promotion campaigns;

- cooperation with national tourist representatives of other countries and national resort associations with the purpose of including regional tourist products into the lists of their offers.

Tourism development in Pribaikalye assumes a set of measures within the limits of the branch policy and infrastructure development as its precondition.

To solve this problem, it is necessary:

- to modify the hotel complex of the region according to modern conditions of development of service;

- to provide enough public catering establishments, game and entertaining establishments in the places of stay of tourists;

- to increase the number of qualified personnel in the sphere of tourist business and hotel industry;

- to create modern infrastructure of mounting skiing resort "Sable Mountain" in Baikalsk;

- to create conditions for updating the park of floating crafts and water moorings for intensification of perspective water tourism;

- to raise transport availability of tourist objects.

Creation of modern tourist and transport infrastructure, promotion of Irkutsk region in the market of tourist services will lead to essential growth of the number of tourists coming to the region. It is predicted that by 2020 the flow of tourists during the summer period will 
make more than 1 million persons. It is, first of all, connected with the plans to construct 48 new hotels with 19 thousand new hotel places by 2020 in the region, of which $60 \%$ will be constructed in the territory of the special economic zone.

Economic growth in Russia as a whole, and an increase in monetary incomes of the population must make Irkutsk region attractive not only for foreign, but also the Russian tourists.

\section{Problems of formation of tourist-recreational complex in Irkutsk Region}

The key direction of economic development of Irkutsk region is forming a recreational complex based on such a unique resource as the lake Baikal as a competitive advantage of the region. It is possible to develop various kinds of tourism here.

Development of the tourist sector may become one of the prime projects of development of interregional cooperation within the limits of the Siberian federal district. There exists a decision of Federal authorities to create in the Irkutsk region a special economic zone of tourist-recreational type, «The Gate of Baikal».

The basic problem is that the material base of the sector has been essentially obsolete and does not correspond to the international standards. The airport «Irkutsk» is one of the bottlenecks.

Another problem is alignment of seasonal prevalence of tourist flows.

In the tourist sector, the practice of private-state partnership seems to be quite effective.

Assist. prof. Elena Gafarova

Irkutsk State Technical University, Russia

e-mail: persik17@mail.ru 